


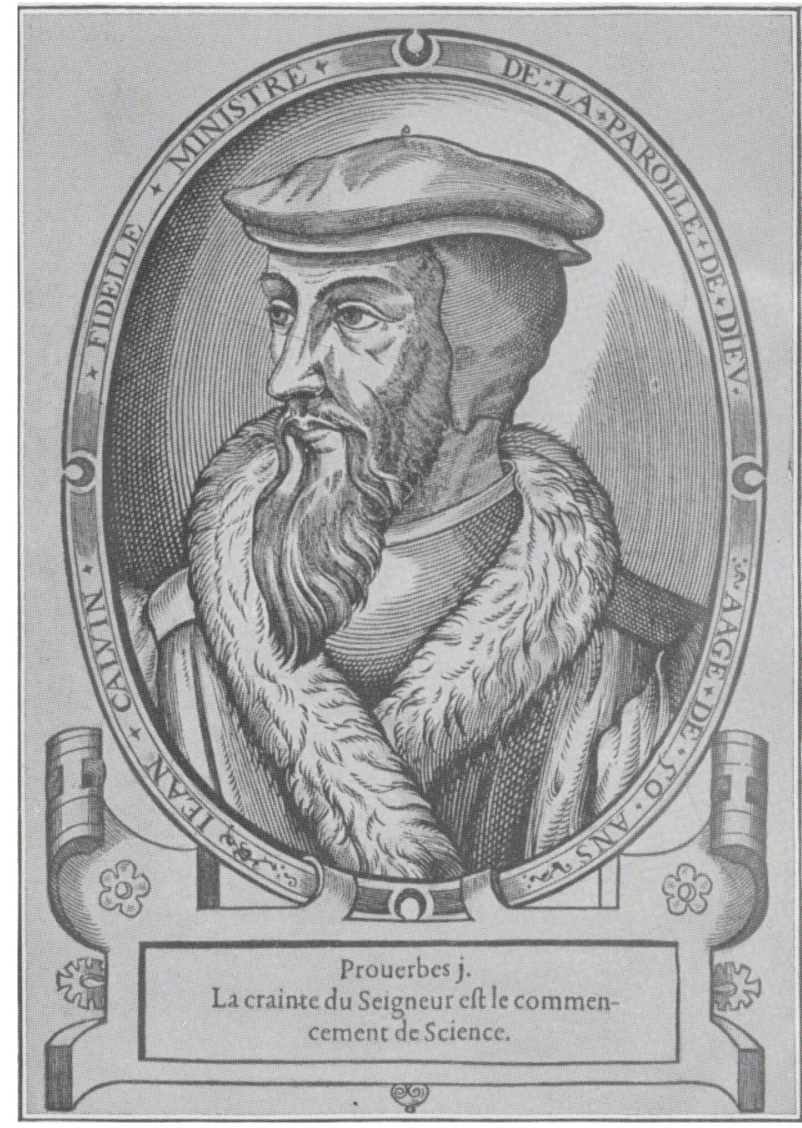

\section{Joḩann Calvin}

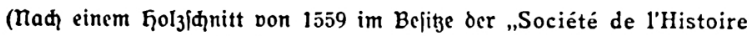
du Protestantisme Français") 


\title{
Johann Calvin
}

pon

\author{
A. Bolfert
}

Deutj币̨e Ausgabe

bejorgt von Prof. Dr. h̨ermann Krollick

Mit dem Bilde des Reformators

Gieß̧en 1908

Derlag von Alfred שöpelmann (pormals I. Riđer) 


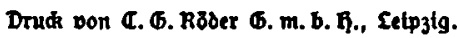

